\title{
Congress smiles on research budgets
}

[WASHINGTON] Major US science agencies are set to enjoy their healthiest budget increases for years, following Congress's agreement to match or exceed most of the funding requests made for them by President Bill Clinton in February.

Despite the expectation of hectic lastminute negotiations between Congress and the White House to finalize the government's budget for the 1999 financial year, which started on 1 October (see Nature 391, 521-522; 1998), the two sides have agreed funding for almost all the major science agencies, apart from the National Institutes of Health (NIH).

Funding for the NIH will probably be caught up in these negotiations. But the biomedical research agency is virtually assured of a significant increase over its 1998 budget of $\$ 13.6$ billion. The House of Representatives is calling for 9 per cent budget growth and the Senate for 14 per cent.

Overall, the federal government's support for basic research is poised to grow substantially in real terms for the first time since the early 1990s. This is despite the failure of the Congress to raise new money from tobacco taxes which Clinton said in February would pay for his science initiatives.

The energy and water appropriations bill, which was completed on 25 September and which Clinton is expected to sign, will support small increases for nuclear and highenergy physics at the Department of Energy, and flat funding for fusion science. But virtually none of the additional money for energy supply research requested by the administration for its Climate Change Technology Initiative has been granted by the Congress (see Nature 394, 305; 1998).

The energy budget contains only $\$ 130$ million of the $\$ 157$ million requested to start building the Spallation Neutron Source at Oak Ridge National Laboratory, raising the likelihood that the facility will open late.

Under an appropriations bill for veterans' affairs, housing and urban development and independent agencies (VA-HUD), agreed by conference between the House and Senate last week, the National Science Foundation will get $\$ 3.67$ billion, a rise of 7 per cent.

The foundation's research account increases by 9 per cent - slightly better than the amount proposed by the Senate, but less than the 12 per cent rise the White House had requested. Following the Senate's lead, funding was denied for the Polar Cap Observatory and $\$ 10$ million was added for plant genome research. But a proposed 5 per cent rise for salaries and expenses, which the Senate had cut, was restored.

The VA-HUD negotiations eased some of NASA's financial problems with a decision to honour the administration's full request of
$\$ 2.27$ billion for the International Space Station - \$170 million more than the House had granted. A House-proposed addition of \$1.6 million for a ground-based asteroid detection programme was trimmed to $\$ 1$ million, and a \$20-million Senate addition for advanced technology for space science was halved.

It is still undecided whether Vice-President Al Gore's proposed Triana Earth-viewing satellite will receive funding (see Nature 394, 213; 1998). Last week's compromise bill omitted a House clause denying money for the project pending a congressional review of the proposals received by NASA. The space agency has a winning concept in mind, and hoped to gain final approval from Congress this week. NASA's overall budget of $\$ 13.7$ billion is $\$ 200$ million more than the White House had requested.

The defence appropriations bill includes increases of 6 per cent for both basic and applied research - the first real rise in six years for the Pentagon programmes which support most engineering and computer

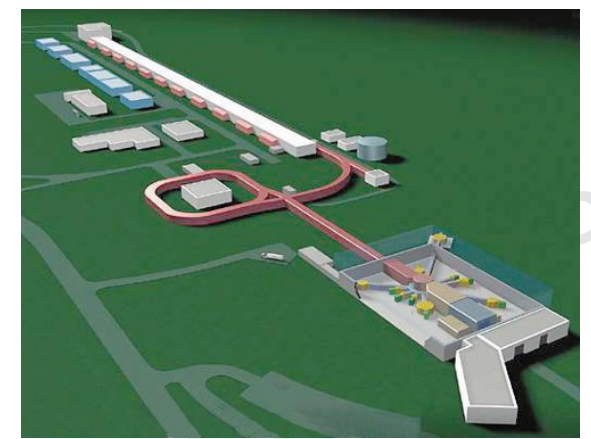

Delayed opening? The Spallation Neutron

Source is funded, but it could be finished late.

science research at US universities.

Budgets for smaller research programmes at the departments of agriculture, commerce and the interior are, like those at NIH, yet to be finalized. These may end up in a single 'omnibus' spending bill which Congress will try to negotiate with Clinton before members return to their districts for November's elections.

Colin Macilwain \& Tony Reichhardt

\section{Brussels rejects 'grace period' on patents}

[PARIS] The European Commission has rejected a proposal that Europe should unilaterally adopt a 'grace period' allowing researchers and inventors to file for a patent up to a year after publishing a discovery.

At present, a patent has to be applied for before publication. This contrasts with the situation in the United States, where a 12month post-publication grace period exists, and a committee of the European Parliament has recently proposed that a similar measure be introduced in Europe.

But a public meeting on the issue organized in Brussels on Monday (5 October) by the European Commission heard industry's view that such a move would be a backwards step. The industrialists agreed that the idea appears superficially attractive, particularly to scientists who have rushed into print before realizing that this sabotages their future patent rights.

But the industrialists say it would disadvantage small companies and academic researchers, particularly as it would open the door to expensive litigation. Many, including the British Technology Group (BTG) and the Union of Industrial and Employers' Confederations of Europe (UNICE), are concerned that a grace period would encourage more researchers to publish before patenting, ignoring the fact that this would open their claims to greater contention.

Whereas priority is attributed in Europe on a clear 'first to file' basis, the US system is based on 'first to invent'. The legal ambiguities that this can create inevitably lead to expensive legal squabbles to establish the paternity of inventions. The United States is the only country to have such a system.

The 'first to invent' system 'makes lawyers very rich and unlucky inventors very poor," says Sue Scott, technology licensing officer of BTG, arguing that the cost of meeting a legal challenge can easily run into "six figure sums".

Patenting before publishing is always a more prudent strategy, argue BTG and UNICE. They point out, for example, that if European inventors published details of their inventions before patenting these, a third party might publish, and apply for patents, on minor modifications that the original inventors might have intended to patent.

Worse, third parties might republish the original invention within the grace period in a form where the copying was not apparent, in a bid to obtain patents. Whatever the drawbacks of the existing European system, it has the advantage of being clear cut. Introducing a "grace period" would only "complicate the current system," says Jérome Chauvin, an adviser to UNICE.

BTG agrees that adoption of a grace period by Europe would be a retrograde step for inventors, and should not be taken unless the United States adopts a first-to-file system.

As the result of a hearing, the commission has abandoned the idea of a grace period "in the near future", according to one official, adding that Brussels will direct its efforts to educating inventors better on the pitfalls of patent law.

Declan Butler \& David Dickson 